\title{
Pengaruh Posisi Skarifikasi Benih dan Perendaman Air Kelapa terhadap Perkecambahan Biji dan Pertumbuhan Bibit Sirsak (Annona muricata L.)
}

\section{The Effect of Seed Scarification Position and Coconut Water Soaking on Seed Germination and Growth of Soursop Seedling (Anona muricata L.)}

\section{Arya Agung Pranata, Asil Barus*, Meiriani}

Program Studi Agroekoteknologi, Fakultas Pertanian, USU, Medan 20155

*Corresponding author : asilbarus24@gmail.com

\begin{abstract}
The problem of generative propagation of soursop is its seeds take a long time to germinate which are caused by the hard seed coat. The solution to solve that problem is scarification and coconut water soaking to simpifly the process of imbibition and seed germination and also stimulate the growth of shoot. This objective of the research was to determine the effect of scarification position and the soaking with various concentration of coconut water on seed germination and growth of soursop seedling. This research was held at Faculty of Agriculture field, University of Sumatera Utara in March - July 2017. The resesarch used factoial randomized block design with two factor and three replication. The first factor is scarification position (without scarification, stomach scarification, top scarification) and the second factor is coconut water soaking $(0 \%$; 25\%; 50\%; $75 \%)$. The result of the research showed that the germination rate parameter, germination percentage, crop height, number of leaves, root volume and dry weight of crop significantly higher on without scarification treatment than with scarification treatment. The interaction between scarification position and soaking with various coconut water concentrations was not significant affecting to the seed germination and growth of soursop seedling.
\end{abstract}

Keywords: soursop, scarification position, coconut water.

\begin{abstract}
ABSTRAK
Permasalahan dalam perbanyakan generatif tanaman sirsak adalah biji yang disemai membutuhkan waktu yang lama untuk berkecambah. Hal tersebut disebabkan oleh tingkat kekerasan kulit bijinya Solusi dari permasalahan tersebut adalah dengan melakukan skarifikasi dan perendaman air kelapa dengan berbagai konsentrasi untuk memudahkan proses imbibisi dan perkecambahan pada biji serta merangsang pertumbuhan tunas. Penelitian ini bertujuan untuk mengetahui pengaruh posisi skarifikasi dan konsentrasi air kelapa terhadap perkecambahan biji dan pertumbuhan bibit sirsak, Penelitian ini dilaksanakan di lahan Fakultas Pertanian, Universitas Sumatera Utara, Pada bulan Maret - Juli 2017 dan menggunakan rancangan acak kelompok dengan dua faktor perlakuan dan tiga ulangan. Faktor pertama adalah posisi skarifikasi (tanpa skarifikasi, skarifikasi bagian perut, skarifikasi bagian ujung) dan faktor kedua adalah perendaman air kelapa $(0 \% ; 25 \% ; 50 \% ; 75 \%)$. Hasil penelitian menunjukkan bahwa peubah amatan laju perkecambahan, persentase perkecambahan, tinggi bibit, jumlah daun, volume akar dan bobot kering bibit nyata lebih tinggi pada perlakuan tanpa skarifikasi dibandingkan dengan perlakuan skarifikasi. Interaksi antara posisi skarifikasi dan perendaman pada berbagai konsentrasi air kelapa tidak berpengaruh nyata terhadap perkecambahan biji dan pertumbuhan bibit sirsak.
\end{abstract}

Kata kunci : sirsak, posisi skarifikasi, air kelapa 


\section{PENDAHULUAN}

Permintaan buah-buahan yang merupakan sumber utama vitamin dan mineral terus mengalami peningkatan di Indonesia yaitu sebesar $12-15$ persen per tahun, sejalan dengan pertumbuhan penduduk dan kesadaran akan faktor kesehatan. Berdasarkan data bahwa secara keseluruhan kebutuhan buah nasional mencapai 19,03 juta ton dan 667 ribu ton berasal dari impor (Krisnamurthi, 2011).

Sirsak merupakan tanaman buah tahunan yang dapat tumbuh dan berbuah sepanjang tahun. Tanaman ini berasal dari daerah tropis di benua Amerika. Sirsak adalah salah satu buah yang memiliki kandungan vitamin $\mathrm{B}$ dan $\mathrm{C}$ cukup tinggi dan digemari masyarakat sebagai buah segar maupun olahan. Sebagai tanaman pekarangan komoditas ini masih terbuka cukup luas untuk dikembangkan (Ashari, 1995).

Perbanyakan tanaman sirsak dapat dilakukan secara generatif dan vegetatif. Masyarakat atau petani pada umumnya memperbanyak sirsak dengan biji. Hasil perbanyakan tanaman sirsak dengan biji kualitas hasilnya tidak kalah dibandingkan tanaman induk. Diharapkan biji akan membawa sifat-sifat baik dari kedua induknya.

Dalam pembudidayaan sirsak secara generatif atau biji terdapat kendala, salah satunya adalah biji yang disemai membutuhkan waktu yang lama untuk berkecambah, dimana kecambah dan tunas tanaman sirsak tumbuh sekitar 2-3 minggu setelah disemai (Purnomosidhi, 2013) yang disebabkan oleh tingkat kekerasan kulitnya, karena semakin keras kulit biji maka waktu yang dibutuhkan untuk menginduksi perkecambahan semakin lama. Untuk itu diperlukan perlakuan benih seperti skarifikasi atau pelukaan benih serta pemberian zat pengatur tumbuh agar dapat menghasilkan pertumbuhan bibit yang cepat dan seragam (Basri, 2005).

Semakin dekat letak masuknya air dengan embrio, maka perkecambahan akan lebih cepat berlangsung. Pematahan dormansi dapat dilakukan dengan skarifikasi atau penggoresan yang mencakup cara-cara mekanik seperti mengikir atau menggosok kulit biji. Dimana semuanya bertujuan agar kulit biji lebih permeabel terhadap air dan gas oksigen $\left(\mathrm{O}_{2}\right)$ (Utomo, 2006).

Penggunaan ZPT alami dapat mempercepat perkecambahan benih karena mengandung hormon yang memacu pertumbuhan tanaman. Bahan alami yang dapat digunakan sebagai sumber ZPT adalah air kelapa, yang mengandung unsur hara dan zat pengatur tumbuh seperti sitokinin dan auksin. Sitokinin diketahui sebagai salah satu zat pengatur tumbuh yang berperan dalam pembelahan sel sehingga dapat menstimulasi proses perkecambahan (Hayati, 2011).

Sujarwati, $d k k$ (2011) menyatakan air kelapa dengan konsentrasi $75 \%$ meningkatkan persentase perkecambahan dan pertumbuhan bibit palem putri. Hasil penelitian Dwipa (1992) dalam Aguzaen (2009) juga menunjukkan bahwa pertumbuhan serta perkembangan akar dan tajuk dari stek lada (cabang orthotop) dapat ditingkatkan dengan perendaman bahan stek selama 8 jam dalam $25 \%$ air kelapa muda, dan untuk bahan stek lada perlu (dari cabang plagiotrop) direndam dalam 25-50 \% air kelapa selama 12 jam

Penelitian ini bertujuan untuk mengetahui pengaruh posisi skarifikasi benih dan konsentrasi perendaman air kelapa terhadap perkecambahan biji dan pertumbuhan bibit sirsak (Annona muricata L.)

\section{BAHAN DAN METODE}

Penelitian ini dilakukan di Lahan Fakultas Pertanian Universitas Sumatera Utara dengan ketinggian tempat \pm 25 meter di atas permukaan laut pada bulan Maret sampai dengan Juli 2017.

Bahan yang digunakan adalah benih tanaman sirsak varietas Ratu yang digunakan sebagai bahan tanam, air kelapa muda, aquades, top soil, pasir, pupuk kompos, bambu, kertas pasir halus, stik es krim, dan dithane M-45. Alat yang digunakan adalah polybag, cangkul, parang, penggaris, gelas 
ukur, beaker glass, ember, ayakan dan gembor.

dengan dua faktor perlakuan yaitu : Faktor pertama : Jenis Posisi Skarifikasi (S) terdiri dari tiga taraf yaitu $S_{1}$ : Tanpa Skarifikasi, $\mathrm{S}_{2}$ : Skarifikasi Bagian Perut Benih dan $\mathrm{S}_{3}$ : Skarifikasi Bagian Ujung Benih. Faktor kedua Perendaman Air Kelapa (K) terdiri dari 4 taraf, yaitu : $\mathrm{K}_{0}: 0 \%, \mathrm{~K}_{1}: 25 \%, \mathrm{~K}_{2}: 50 \%$, dan $\mathrm{K}_{3}: 75 \%$.

Pelaksanaan penelitian meliputi persiapan lahan dengan cara dibersihkan dari gulma dan digemburkan, pembuatan plot dengan ukuran $1 \times 1 \mathrm{~m}$ sebanyak 36 buah, pembuatan naungan dengan ukuran yang disesuaikan dengan ukuran lahan, persiapan media tanam berupa campuran topsoil, pasir dan kompos dengan perbandingan 1:1:1, persiapan bahan tanam dengan membersihkan biji sirsak dari daging buah, persiapan air kelapa dengan membuat larutan air kelapa sesuai perlakuan, proses skarifikasi dengan menggosok biji dengan kertas amplas, pemberian perlakuan air kelapa dengan perendaman biji selama 24 jam dan penanaman, pemeliharaan yang terdiri dari penyiraman yang dilakukan pada sore hari, penyiangan apabila terdapat gulma pada lahan, serta kegiatan pengendalian hama dan penyakit apabila tanaman terserang hama dan penyakit. Peubah yang diamati adalah laju perkecambahan, persentase perkecambahan, tinggi bibit, jumlah daun, panjang akar, volume akar dan bobot kering bibit. Data dianalisis dengan sidik ragam, sidik ragam yang nyata dilanjutkan dengan menggunakan
Penelitian ini menggunakan Rancangan Acak Kelompok (RAK) faktorial Uji Jarak Berganda Duncan dengan taraf $\alpha=5 \%$

\section{HASIL DAN PEMBAHASAN}

\section{Laju Perkecambahan}

Laju perkecambahan benih sirsak umur 40 HST pada berbagai posisi skarifikasi dan perendaman air kelapa dapat dilihat pada Tabel 1.

Tabel 1 menunjukkan bahwa, perlakuan tanpa skarifikasi $\left(\mathrm{S}_{1}\right)$ adalah nyata mempercepat laju perkecambahan walaupun berbeda tidak nyata dengan perlakuan skarifikasi ujung $\left(S_{3}\right)$ dan juga laju perkecambahan tercepat cenderung diperoleh pada perlakuan $\mathrm{K}_{3}$ yaitu perendaman larutan air kelapa dengan konsentrasi $75 \%$ yakni sebesar 19,99 yang berbeda tidak nyata dengan perlakuan lainnya.

Hal ini disebabkan terdapatnya liang biji yang memungkinkan masuknya air pada proses perendaman benih sehingga proses perkecambahan dapat terjadi. Sutopo (2002) menyatakan bahwa, pada awal fase perkecambahan, biji membutuhkan air untuk mulai berkecambah, yang terpenuhi dengan menyerap air secara imbibisi dari lingkungan. Setelah menyerap air maka biji akan membesar dan kulit pecah, kemudian enzimenzim mulai aktif, terutama enzim yang berfungsi mengubah lemak menjadi energi melalui proses respirasi.

Tabel 1. Laju perkecambahan benih tanaman sirsak pada berbagai posisi skarifikasi dan konsentrasi air kelapa

\begin{tabular}{llllll} 
& \multicolumn{5}{c}{ Konsentrasi Air Kelapa (\%) } \\
\cline { 2 - 6 } Posisi Skarifikasi & $\mathrm{K}_{0}$ & $\mathrm{~K}_{1}$ & $\mathrm{~K}_{2}$ & $\mathrm{~K}_{3}$ & Rataan
\end{tabular}




\begin{tabular}{lccccc} 
& $0 \%$ & $25 \%$ & $50 \%$ & $75 \%$ & \\
\hline & ----------------- \\
S $_{1}:$ Tanpa Skarifikasi & 18,53 & 19,73 & 20,87 & 20,04 & $19,79 \mathrm{~b}$ \\
$\mathrm{~S}_{2}:$ Skarifikasi Bagian Perut & 24,52 & 20,65 & 21,78 & 20,98 & $21,98 \mathrm{a}$ \\
$\mathrm{S}_{3}:$ Skarifikasi Bagian Ujung & 19,62 & 20,73 & 20,13 & 18,95 & $19,86 \mathrm{~b}$ \\
\hline Rataan & 20,89 & 20,37 & 20,93 & 19,99 & \\
\hline
\end{tabular}

Keterangan: Angka yang diikuti oleh huruf yang sama pada kolom yang sama menunjukkan berbeda tidak nyata menurut Uji Jarak Berganda Duncan pada taraf $\alpha=5 \%$.

Tabel 2. Persentase perkecambahan benih tanaman sirsak pada berbagai posisi skarifikasi dan konsentrasi air kelapa

\begin{tabular}{|c|c|c|c|c|c|}
\hline \multirow{3}{*}{ Posisi Skarifikasi } & \multicolumn{5}{|c|}{ Konsentrasi Air Kelapa (\%) } \\
\hline & $\mathrm{K}_{0}$ & $\mathrm{~K}_{1}$ & $\mathrm{~K}_{2}$ & $\mathrm{~K}_{3}$ & Rataan \\
\hline & $0 \%$ & $25 \%$ & $50 \%$ & $75 \%$ & \\
\hline & - & - & --0 & 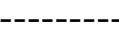 & ---- \\
\hline $\mathrm{S}_{1}$ : Tanpa Skarifikasi & 89,58 & 87,5 & 83,33 & 91,67 & $88,02 \mathrm{a}$ \\
\hline$S_{2}:$ Skarifikasi Bagian Perut & 33,33 & 31,25 & 50 & 29,17 & $35,94 \mathrm{c}$ \\
\hline $\mathrm{S}_{3}$ : Skarifikasi Bagian Ujung & 64,58 & 68,75 & 77,08 & 66,67 & $69,27 b$ \\
\hline Rataan & 62,5 & 62,5 & 70,14 & 62,5 & \\
\hline
\end{tabular}

Keterangan: Angka yang diikuti oleh huruf yang sama pada kolom yang sama menunjukkan berbeda tidak nyata menurut Uji Jarak Berganda Duncan pada taraf $\alpha=5 \%$.

\section{Persentase Perkecambahan}

Laju perkecambahan benih sirsak umur 30 HST pada berbagai posisi skarifikasi dan perendaman air kelapa dapat dilihat pada Tabel 2.

Tabel 2 menunjukkan bahwa, perlakuan tanpa skarifikasi $\left(\mathrm{S}_{1}\right)$ adalah nyata menghasilkan persentase perkecambahan tertinggi daripada perlakuan lainnya dan juga persentase perkecambahan tertinggi cenderung diperoleh pada perlakuan $\mathrm{K}_{2}$ yaitu perendaman larutan air kelapa dengan konsentrasi $50 \%$ yakni sebesar 70,14 yang berbeda tidak nyata dengan perlakuan lainnya.

Pada peubah amatan persentase perkecambahan perlakuan tanpa skarifikasi $\left(\mathrm{S}_{1}\right)$ adalah nyata menghasilkan persentase perkecambahan tertinggi dibanding perlakuan lainnya. Perlakuan benih yang diskarifikasi memberikan persentase perkecambahan yang rendah. Hal ini disebabkan karena benih yang telah mendapatkan perlakuan skarifikasi lebih mudah terkena serangan patogen yang terdapat dalam tanah atau media tanam yang lembab. Luka pada biji akibat proses skarifikasi mempermudah masuk dan berkembangnya patogen yang menyebabkan benih rusak dan mati sehingga proses perkecambahan tidak terjadi. Sutopo (2002) menyatakan bahwa, benih dikatakan sehat apabila bebas dari patogen, baik berupa bakteri, cendawan, virus maupun nematoda. Penyakit yang ditimbulkannya kemungkinan dapat terjadi pada kecambah, tanaman muda ataupun tanaman yang telah dewasa. Selain itu kesehatan benih juga dapat menurun akibat karena kerusakan fisik yang memudahkan patogen tertentu dapat berkembang dan menurunkan kualitas. 
Tabel 3. Tinggi bibit tanaman sirsak pada berbagai posisi skarifikasi dan konsentrasi air kelapa umur 12 MST

\begin{tabular}{|c|c|c|c|c|c|}
\hline \multirow{3}{*}{ Posisi Skarifikasi } & \multicolumn{5}{|c|}{ Konsentrasi Air Kelapa (\%) } \\
\hline & $\mathrm{K}_{0}$ & $\mathrm{~K}_{1}$ & $\mathrm{~K}_{2}$ & $\mathrm{~K}_{3}$ & Rataan \\
\hline & $0 \%$ & $25 \%$ & $50 \%$ & $75 \%$ & \\
\hline & & -- & $-----c$ & & --- \\
\hline $\mathrm{S}_{1}:$ Tanpa Skarifikasi & 20,71 & 20,91 & 19,47 & 20,78 & $20,47 \mathrm{a}$ \\
\hline $\mathrm{S}_{2}$ : Skarifikasi Bagian Perut & 19,51 & 19,03 & 18,91 & 21,01 & $19,61 \mathrm{a}$ \\
\hline $\mathrm{S}_{3}:$ Skarifikasi Bagian Ujung & 19,37 & 19,03 & 15,92 & 18,77 & $18,27 \mathrm{~b}$ \\
\hline Rataan & $19,86 \mathrm{a}$ & $19,66 \mathrm{a}$ & $18,10 \mathrm{~b}$ & $20,19 a$ & \\
\hline
\end{tabular}

Keterangan: Angka yang diikuti oleh huruf yang sama pada kolom yang sama menunjukkan berbeda tidak nyata menurut Uji Jarak Berganda Duncan pada taraf $\alpha=5 \%$.

\section{Tinggi Bibit}

Tinggi bibit tanaman sirsak umur 12 MST pada berbagai posisi skarifikasi dan perendaman air kelapa dapat dilihat pada Tabel 3.

Tabel 3 menunjukkan bahwa, pada tanaman sirsak umur 12 MST, perlakuan tanpa skarifikasi $\left(\mathrm{S}_{1}\right)$ adalah nyata menghasilkan tinggi bibit tertinggi daripada perlakuan lainnya dan perlakuan perendaman larutan air kelapa dengan konsentrasi $75 \%$ $\left(\mathrm{K}_{3}\right)$ adalah nyata menghasilkan tinggi bibit tertinggi walaupun berbeda tidak nyata dengan perlakuan perendaman larutan air kelapa dengan konsentrasi $0 \%\left(\mathrm{~K}_{1}\right)$ dan $25 \%$ $\left(\mathrm{K}_{2}\right)$.

Pada peubah amatan tinggi bibit, perlakuan tanpa skarifikasi $\left(\mathrm{S}_{1}\right)$ dan perendaman larutan air kelapa dengan konsentrasi $75 \% \quad\left(\mathrm{~K}_{3}\right)$ adalah nyata menghasilkan tinggi tanaman tertinggi dibandingkan perlakuan lainnya. Hal ini disebabkan oleh benih yang mendapat perlakuan skarifikasi dan tidak diskarifikasi direndam dengan air kelapa dengan konsentrasi sesuai perlakuan selama 24 jam. Waktu perendaman yang cukup lama menyebabkan air dapat masuk kedalam benih, serta hormon sitokinin, auksin dan giberelin dan senyawa lain yang terdapat pada larutan air kelapa sebanyak $75 \%$ merupakan konsentrasi yang tepat dalam memacu pertumbuhan tanaman sirsak. Sutopo (2002) menyatakan bahwa, setiap biji tanaman mempunyai kisaran waktu yang tertentu untuk bisa berkecambah. Pada proses perkecambahan, lama perendaman yang tepat dapat membantu mematahkan masa dormansi yang menghambat proses perkecambahan. Lawalata (2011) juga menyatakan bahwa, air kelapa muda merupakan suatu bahan alami dimana di dalamnya terkandung hormon seperti sitokinin $5,8 \mathrm{mg} / \mathrm{l}$ yang dapat merangsang pertumbuhan tunas dan mengaktifkan kegiatan jaringan atau sel hidup, auksin 0,07 mg/l dan sedikit giberelin serta senyawa lain yang dapat menstimulasi perkecambahan dan pertumbuhan.

\section{Jumlah Daun}

Jumlah daun tanaman sirsak umur 12 MST pada berbagai posisi skarifikasi dan perendaman air kelapa dapat dilihat pada Tabel 4.

Tabel 4 menunjukkan bahwa, pada tanaman sirsak umur 12 MST, perlakuan tanpa skarifikasi $\left(\mathrm{S}_{1}\right)$ adalah nyata menghasilkan jumlah daun tertinggi daripada perlakuan lainnya perlakuan konsentrasi air kelapa $75 \%\left(\mathrm{~K}_{3}\right)$ adalah nyata menghasilkan jumlah daun tertinggi walaupun berbeda tidak nyata dengan perlakuan $0 \%\left(\mathrm{~K}_{0}\right)$ dan $25 \%$ $\left(\mathrm{K}_{1}\right)$.

Jumlah daun tertinggi didapatkan dari perlakuan tanpa skarifikasi $\left(\mathrm{S}_{1}\right)$ dan perendaman larutan air kelapa dengan konsentrasi $75 \%\left(\mathrm{~K}_{3}\right)$, sejalan dengan tinggi tanaman yang didapatkan dari perlakuan 
Tabel 4. Jumlah daun tanaman sirsak pada berbagai posisi skarifikasi dan konsentrasi air kelapa umur 12 MST

\begin{tabular}{|c|c|c|c|c|c|}
\hline \multirow{3}{*}{ Posisi Skarifikasi } & \multicolumn{5}{|c|}{ Konsentrasi Air Kelapa (\%) } \\
\hline & $\overline{\mathrm{K}_{0}}$ & $\overline{\mathrm{K}_{1}}$ & $\overline{\mathrm{K}_{2}}$ & $\mathrm{~K}_{3}$ & Rataan \\
\hline & $0 \%$ & $25 \%$ & $50 \%$ & $75 \%$ & \\
\hline & & & & & -------- \\
\hline $\mathrm{S}_{1}$ : Tanpa Skarifikasi & 11,33 & 11,08 & 10,5 & 10,92 & $10,96 \mathrm{a}$ \\
\hline $\mathrm{S}_{2}$ : Skarifikasi Bagian Perut & 10,58 & 9,67 & 9,75 & 10,83 & $10,21 b$ \\
\hline $\mathrm{S}_{3}$ : Skarifikasi Bagian Ujung & 10,58 & 10,92 & 9,17 & 10,83 & $10,38 \mathrm{ab}$ \\
\hline Rataan & $10,83 a$ & $10,56 \mathrm{a}$ & $9,81 \mathrm{~b}$ & $10,86 \mathrm{a}$ & \\
\hline
\end{tabular}

Keterangan: Angka yang diikuti oleh huruf yang sama pada kolom yang sama menunjukkan berbeda tidak nyata menurut Uji Jarak Berganda Duncan pada taraf $\alpha=5 \%$.

yang berbeda tidak nyata dengan perlakuan lainnya dan juga nilai panjang akar tanaman tertinggi cenderung diperoleh pada perlakuan

Yadi (2012) menyatakan bahwa, jumlah daun dipengaruhi oleh lingkungan tumbuh serta ketersediaan unsur hara. Hal ini juga didukung oleh pendapat Wiguna (2009) yang menyatakan bahwa, tanaman yang lebih tinggi akan menghasilkan daun yang lebih banyak sehingga hasil fotosintesis yang berfungsi bagi pembentukan buah akan semakin banyak.

\section{Panjang Akar}

Berdasarkan data pengamatan dan hasil sidik ragam diketahui bahwa perlakuan posisi skarifikasi dan perendaman air kelapa serta interaksi antara kedua perlakuan berpengaruh tidak nyata terhadap panjang akar tanaman sirsak.

Tabel 5 menunjukkan bahwa, pada tanaman sirsak umur 12 MST, nilai panjang akar tertinggi cenderung diperoleh pada perlakuan tanpa skarifikasi $\left(\mathrm{S}_{1}\right)$ yaitu 18,19
$\mathrm{K}_{0}$ yaitu konsentrasi air kelapa $0 \%$ yakni sebesar 18,27 yang berbeda tidak nyata dengan perlakuan lainnya

Peran zat pengatur tumbuh yang terdapat didalam air kelapa yaitu sitokinin dan auksin yang seharusnya menjadi substansi pertumbuhan untuk pembentukan dan perkembangan akar belum mampu berpengaruh secara optimal. Hal ini disebabkan karena kandungan hormon yang terdapat didalam tumbuhan sudah mencukupi dalam pembentukan dan perkembangan akar sehingga pemberian yang diberikan dari luar tidak berpengaruh terhadap tanaman. Hal ini sesuai dengan literatur Mahardika (2013) yang menyatakan bahwa, pemberian zat pengatur tumbuh bertujuan untuk mempercepat proses fisiologi pada tanaman yang memungkinkan tersedianya bahan pembentuk organ vegetatif, sehingga dapat meningkatkan zat hara yang tersedia.

Tabel 5. Panjang akar bibit tanaman sirsak pada berbagai posisi skarifikasi dan konsentrasi air kelapa

\begin{tabular}{|c|c|c|c|c|c|}
\hline \multirow{3}{*}{ Posisi Skarifikasi } & \multicolumn{5}{|c|}{ Konsentrasi Air Kelapa (\%) } \\
\hline & $\mathrm{K}_{0}$ & $\mathrm{~K}_{1}$ & $\mathrm{~K}_{2}$ & $\mathrm{~K}_{3}$ & Rataan \\
\hline & $0 \%$ & $25 \%$ & $50 \%$ & $75 \%$ & \\
\hline $\mathrm{S}_{1}$ : Tanpa Skarifikasi & 19,15 & 17,23 & 18,54 & 17,84 & 18,19 \\
\hline
\end{tabular}




\begin{tabular}{llllll}
$\mathrm{S}_{2}:$ Skarifikasi Bagian Perut & 18,03 & 16,59 & 17,06 & 17,57 & 17,31 \\
$\mathrm{~S}_{3}:$ Skarifikasi Bagian Ujung & 17,64 & 17,58 & 15,57 & 16,89 & 16,92 \\
\hline Rataan & 18,27 & 17,13 & 17,06 & 17,43 & \\
\hline
\end{tabular}

Tabel 6. Volume akar bibit tanaman sirsak pada berbagai posisi skarifikasi dan konsentrasi air kelapa

\begin{tabular}{|c|c|c|c|c|c|}
\hline \multirow[b]{2}{*}{ Posisi Skarifikasi } & \multicolumn{5}{|c|}{ Konsentrasi Air Kelapa (\%) } \\
\hline & $\begin{array}{c}\mathrm{K}_{0} \\
0 \%\end{array}$ & $\begin{array}{c}\mathrm{K}_{1} \\
25 \%\end{array}$ & $\begin{array}{c}\mathrm{K}_{2} \\
50 \%\end{array}$ & $\begin{array}{c}\mathrm{K}_{3} \\
75 \%\end{array}$ & Rataan \\
\hline $\mathrm{S}_{1}$ : Tanpa Skarifikasi & 0,85 & 0,87 & 1,03 & 0,88 & $0,91 \mathrm{a}$ \\
\hline $\mathrm{S}_{2}$ : Skarifikasi Bagian Perut & 0,78 & 0,77 & 0,83 & 0,8 & $0,80 \mathrm{~b}$ \\
\hline $\mathrm{S}_{3}:$ Skarifikasi Bagian Ujung & 0,67 & 0,62 & 0,52 & 0,65 & $0,61 \mathrm{c}$ \\
\hline Rataan & 0,77 & 0,75 & 0,79 & 0,78 & \\
\hline
\end{tabular}

Keterangan: Angka yang diikuti oleh huruf yang sama pada kolom yang sama menunjukkan berbeda tidak nyata menurut Uji Jarak Berganda Duncan pada taraf $\alpha=5 \%$.

\section{Volume Akar}

Volume akar tanaman sirsak umur 12 MST pada berbagai posisi skarifikasi dan perendaman air kelapa dapat dilihat pada Tabel 6.

Tabel 6 menunjukkan bahwa, pada tanaman sirsak umur 12 MST, perlakuan tanpa skarifikasi $\left(\mathrm{S}_{1}\right)$ adalah nyata menghasilkan volume akar tertinggi daripada perlakuan lainnya dan juga volume akar tanaman tertinggi cenderung diperoleh pada perlakuan $\mathrm{K}_{2}$ yaitu perendaman larutan air kelapa dengan konsentrasi $50 \%$ yakni sebesar 0,79 yang berbeda tidak nyata dengan perlakuan lainnya.

Semakin banyak jumlah daun dan semakin tinggi tanaman, maka volume akar yang dihasilkan juga besar hal ini sejalan dengan peubah amatan volume akar dimana volume akar terbesar diperoleh pada perlakuan tanpa skarifikasi $\left(\mathrm{S}_{1}\right)$. Tausch (2009) menyatakan bahwa, kondisi suatu bagian tegakan tanaman dapat digunakan untuk memperkirakan kondisi bagian yang lain. Hal tersebut umumnya dimanfaatkan untuk mengetahui kualitas tegakan tanaman khususnya pada tanaman-tanaman produksi. Lebih lanjut Chiraz (2013) menunjukan bahwa, terdapat hubungan yang erat antara tinggi tegakan, diameter batang, cakupan akar dan diameter kanopi. Hal ini juga didukung oleh pendapat Komiyama (2008) yang menyatakan bahwa, ukuran tegakan juga menentukan biomassa tanaman baik yang berada diatas permukaan tanah (batang, daun) maupun yang berada dibawah permukaan tanah (akar).

Bobot kering bibit tanaman sirsak umur 12 MST pada berbagai posisi skarifikasi dan perendaman air kelapa dapat dilihat pada Tabel 7.

Tabel 7 menunjukkan bahwa, pada tanaman sirsak umur 12 MST, perlakuan tanpa skarifikasi $\left(\mathrm{S}_{1}\right)$ adalah nyata menghasilkan bobot kering bibit tertinggi daripada perlakuan lainnya dan perlakuan $\mathrm{K}_{0}$ yaitu perendaman larutan air kelapa konsentrasi $0 \%$ adalah nyata menghasilkan bobot kering bibit tertinggi walaupun berbeda tidak nyata dengan perlakuan perendaman larutan air kelapa dengan konsentrasi $75 \%$ $\left(\mathrm{K}_{3}\right)$.

\section{Bobot Kering Bibit}

Pada peubah amatan bobot kering tanaman, perlakuan tanpa skarifikasi $\left(\mathrm{S}_{1}\right)$ dan perendaman larutan air kelapa dengan konsentrasi $75 \quad \% \quad\left(\mathrm{~K}_{3}\right)$ adalah nyata menghasilkan bobot kering tanaman tertinggi dibandingkan perlakuan lainnya. Hal ini juga 
sejalan dengan tinggi jumlah daun, tinggi tanaman dan volume akar yang juga dihasilkan dari perlakuan tanpa skarifikasi
$\left(\mathrm{S}_{1}\right)$ dan perendaman larutan air kelapa dengan konsentrasi $75 \%\left(\mathrm{~K}_{3}\right)$.

Tabel 7. Bobot kering bibit tanaman sirsak pada berbagai posisi skarifikasi dan konsentrasi air kelapa

\begin{tabular}{|c|c|c|c|c|c|}
\hline \multirow{3}{*}{ Posisi Skarifikasi } & \multicolumn{5}{|c|}{ Konsentrasi Air Kelapa (\%) } \\
\hline & $\mathrm{K}_{0}$ & $\mathrm{~K}_{1}$ & $\mathrm{~K}_{2}$ & $\mathrm{~K}_{3}$ & Rataan \\
\hline & $0 \%$ & $25 \%$ & $50 \%$ & $75 \%$ & \\
\hline $\mathrm{S}_{1}$ : Tanpa Skarifikasi & 1,09 & 1,01 & 0,97 & 0,99 & $1,02 \mathrm{a}$ \\
\hline $\mathrm{S}_{2}$ : Skarifikasi Bagian Perut & 0,89 & 0,79 & 0,85 & 1 & $0,88 \mathrm{~b}$ \\
\hline $\mathrm{S}_{3}:$ Skarifikasi Bagian Ujung & 0,86 & 0,83 & 0,6 & 0,86 & $0,79 \mathrm{c}$ \\
\hline Rataan & $0,95 \mathrm{a}$ & $0,88 \mathrm{ab}$ & $0,81 b$ & $0,95 \mathrm{a}$ & \\
\hline
\end{tabular}

Keterangan: Angka yang diikuti oleh huruf yang sama pada kolom yang sama menunjukkan berbeda tidak nyata menurut Uji Jarak Berganda Duncan pada taraf $\alpha=5 \%$.

Jumlah daun, tinggi tanaman dan volume akar akan mempengaruhi jumlah bobot kering yang dihasilkan oleh tanaman. Sumarsono (2008) menyatakan bahwa, akumulasi bahan kering sangat disukai sebagai ukuran pertumbuhan. Akumulasi bahan kering mencerminkan kemampuan tanaman dalam mengikat energi dari cahaya matahari melalui proses fotosintesis, serta interaksinya dengan faktor-faktor lingkungan lainnya. Distribusi akumulasi bahan kering pada bagian-bagian tanaman seperti akar, batang, daun dan bagian generatif, dapat mencerminkan produktivitas tanaman

\section{SIMPULAN}

Laju perkecambahan, persentase perkecambahan, tinggi bibit, jumlah daun, volume akar dan bobot kering bibit nyata lebih tinggi pada perlakuan tanpa skarifikasi dan tidak terdapat interaksi perlakuan antara posisi skarifikasi dengan perendaman air kelapa terhadap perkecambahan biji dan pertumbuhan bibit tanaman sirsak.

\section{DAFTAR PUSTAKA}

Aguzaen, H. 2009. Respon Pertumbuhan Bibit Stek Lada (Piper nigrum L.) Terhadap Pemberian Air Kelapa dan Berbagai Jenis CMA. Jurnal
Agronobis, Vol. 1 (1) : 2-3. Fakultas Pertanian Universitas Andalas, Padang.

Ashari, S. 1995. Hortikultura Aspek Budidaya. UI Press, Jakarta.

Basri, H. 2005. Pengaruh Air Kelapa Muda Terhadap Perkecambahan Biji Wijen (Sesanum indicum L.). Skripsi. Fakultas MIPA. STKIP PGRI Sumatera Barat, Padang.

Chiraz, M.C. 2013. Growth of Young Olive Trees: Water Requirement in Relation to Canopy and Root Development. American Journal of Plant Sciences Vol. 4: 1316 - 1344.

Hayati, A. 2011. Pengaruh Frekuensi dan Konsentrasi Pemberian Air Kelapa Terhadap Pertumbuhan dan Hasil Jamur Merang (Volvariella volvaceae). Skripsi. Fakultas Pertanian Universitas Jember, Jember.

Krisnamurthi, B. 2011. Permintaan Buah Buahan Nasional Tumbuh 12-15 persen.http://www.investor.co.id/agri business/permintaan - buah - buahan nasional - tumbuh - 1215 / 15262. Diakses pada tanggal 22 Januari 2017

Lawalata, I. J. 2011. Pemberian Beberapa Kombinasi ZPT Terhadap Regenerasi Tanaman Gloxinia 
(Siningia speciosa) dari Eksplan Batang dan Daun Secara In Vitro. Jurnal Exp. Life Sci. Vol. 1(2) : 8384. Fakultas Pertanian Universitas Pattimura, Ambon.

Mahardika, I. K. D. 2013. Pengaruh Komposisi Campuran Bahan Media Tanaman Konsentrasi IBA Terhadap Pertumbuhan Bibit Ngumpen Bali (Mangiforea caesia Jack.) Skripsi. Fakultas Pertanian. Universitas Udayana, Bali.

Purnomosidhi, P. 2013. Perlakuan Benih Sebelum Disemai untuk Beberapa Jenis Tanaman Priorotas Kehutanan, Multiguna, Buah-Buahan dan Perkebunan. Lembar Informasi World Agroforestry Centre. AgFor Sulawesi No. 4, Bogor.

Sujarwati, Siti, F., Elna J. dan Herlina. 2011. Penggunaan Air Kelapa untuk Meningkatkan Perkecambahan dan Pertumbuhan Palem Putri (Veitchia merillii). Jurnal SAGU Vol 10 (1) : 24-28. Fakultas MIPA Universitas Riau, Pekanbaru.

Sumarsono, S. 2008. Prosiding Seminar Nasional Pengembangan Usaha Pembibitan Ternak Pola Integrasi
Tanaman Ternak dalam Rangka Mendukung Kecukupan Daging. Universitas Sebelas Maret, Surakarta. Hal : 36-41.

Sutopo, L. 2002. Teknologi Benih. Raja Grafindo Persada, Jakarta.

Tausch, R.J. 2009. A Structurally Based Analytic Model for Estimation of Biomass and Fuel Loads of Woodland Trees. Natural Resource Modeling Vol. 22(4): 463 - 48.

Utomo, B., 2006. Ekologi Benih. Karya Ilmiah Fakultas Pertanian. Universitas Sumatera Utara, Medan

Yadi, S. 2012. Pengaruh Pemangkasan dan Pemberian Pupuk Organik Terhadap Produksi Tanaman Mentimun (Cucumis sativus L.) Jurnal Penelitian Agronomi Vol.1 (2) : 107 114. Fakultas Pertanian Unhalu, Kendari. 